\title{
Development Of Smart Binoculars Learning For Trigonometry Materials In Middle Vocational School
}

\author{
Ferry Kurniawan, Moh. Mahfud Effendi, Siti Khoiruli Ummah \\ Study Program of Mathematics Education, Faculty of Teacher Training and Education \\ University of Muhammadiyah Malang \\ E-mail : kurniawanferry78@gmail.com
}

\begin{abstract}
The purpose of this research is to develop smart binoculars learning media for trigonometry material in Vocational Schools so that it can help and facilitate mathematics teachers in explaining one of the concepts of trigonometry material. The type of research used in this research is Research and Development (R\&D) while the development of instructional media refers to the modified Borg and Gall model, namely research and collection, planning, product draft development, expert validation, small-scale trials. The development has three criteria, namely valid, practical and effective. The results showed that obtained from filling out the validation sheet by the material expert and media expert validators were in the valid category. Furthermore, the practicality of smart binoculars learning media based on student response questionnaire the average student is satisfied with the learning experience using learning media and for the effectiveness of smart binoculars learning media get positive things because the evaluation of ten samples of students gets grades above minimal completeness criteria.
\end{abstract}

Keywords: Manipulative Learning Media; Smart Binoculars; Trigonometry

\section{INTRODUCTION}

Mathematics is one of the subjects that can improve thinking skills (Fajriah and Soraya 2017). Besides mathematics can also be said as a language, which according to Dantzig mathematics is a language of science and according to Jacobs mathematics is a universal language (Prayitno, Suwarsono, and Siswono 2013). One of the scopes of mathematics subject in Vocational School covers trigonometry (Ministry of Education and Culture 2013). Based on the results of an interview with one of the teachers of vocational high School 11 Malang, the majority of vocational high school students have difficulty in learning trigonometry, especially basic competencies applying the rules of sine and cosine, especially when it comes to the application of the use of trigonometric formulas. This results in student learning outcomes trigonometric basic competencies are still below the minimal completeness criteria.

Trigonometry is a branch of mathematics that deals with triangular angles and trigonometric functions such as sines, cosines, and tangents (Kemendikbud 2013). The basis of Trigonometry itself is the concept of the construction of right-angled triangles, the corresponding sides of two similarly built shapes having the same ratio (Djumanta and Susanti 2008). With Euclid's geometry, if each corner of the two triangles has the same size, then the two triangles must be congruent (Sari, Suharsono, and Ansori 2013). There are many applications of trigonometry especially the triangulation technique used in astronomy to calculate distances to nearby stars, in geography to count between certain points, and in satellite navigation systems. Other fields that use trigonometry include 
various branches in physics, land surveying and geodesy, architecture, phonetics, economics, electrical engineering, mechanical engineering, civil engineering, computer graphics, cartography, and many others (Kariadinata 2013).

Based on this, students are expected to be able to solve every problem related to trigonometry. However, if viewed from the results of learning mathematics in Indonesia, including trigonometric learning in vocational schools is still far from satisfying, it can even be said to be still disappointing. This can be seen from the results of the national exams from year to year, for mathematics in which trigonometry is included in the "low" category (Al. Krismanto 2008). This is in line with what was stated by Zulkardi that the acquisition of the National Examination at the vocational high school level is known to be still low and has not experienced significant improvement. These include trigonometry, which is a subject that is difficult for students to master (Dwiatmoko, Rosa, and Gunawan 2015). One effort that can be done to improve the quality of learning, especially trigonometry in vocational schools, is to learn mathematics through media-based learning. Learning by using the right media, will provide optimal results for students' understanding of the material being studied. Sundayana (2014) states that with the learning media, students will take part in more mathematics lessons happily and happily so that their interest in learning mathematics is greater.

Teachers need effective and interesting teaching aids to facilitate students in learning Trigonometry material. As stated by Piaget, effective teaching aids can help students understand simple concepts that must be mastered so that they can link simple concepts into more complex concepts. Budiani (2017) mentions that understanding the concept of trigonometric material is very important. One educational figure who is very concerned about the importance of using teaching aids for students is Maria Montessori. Lillard mentions props based on characteristics: (1) interesting, (2) has gradations, (3) has error control, and (4) can teach students independently (Nugrahanta et al. 2016). Montessori argues that education must help children to overcome problems encountered in everyday life so that children can do everything independently. Learning independently, children can construct their knowledge independently with the help of the surrounding environment (Leong 2006).

Arsyad (2011) said that learning media is a tool in the learning process both inside and outside the classroom, further explained that learning media is a component of learning resources or a physical vehicle containing instructional material in the student environment that can stimulate students to learn. Widyantini and Sigit (2010) revealed that the same as smart binoculars clinometers are very efficient media in teaching trigonometry material. Smart Binoculars are tools used to measure the height and width of an object by utilizing the elevation angle. But in this modern era, the tools used to calculate an object have increasingly developed, to produce an accurate height, it needs to be supported by tools that have high accuracy as well, such as Theodolite. Unfortunately, this tool is too expensive and not practical if used by the community (Hamalik 1982). Smart Binoculars is a simple tool, where its use is very practical, namely pointing the end of the Smart Binoculars at the object, see at what scale the thread falls, and the results will be read directly on the protractor in the Smart Binoculars. Its simplicity and practicality make researchers interested in making Smart Binoculars a thesis research study.

Smart Binoculars are the result of the development of a simple clinometer that already exists, the advantage of Smart Binoculars is that researchers can calculate the height and width of an object. Smart Binoculars are made from wood with a pipe attached 
to a protractor and wooden blocks as support. These Smart Binoculars was developed through several experiments, the first time it was made was a mini theodolite product that could be directly used to examine the elevation angle of the observer with an object but was limited to calculating the height of an object only (frick 1979), but after going through several trials and consultations with some colleagues found a weakness of the minitheodolite that is not its own advantages. Smart Binoculars that the authors have developed have advantages over a simple clinometer developed by other researchers, namely the addition of determining the width of an object. Based on the background explanation above, the researchers wanted research aimed at developing smart binoculars learning media for trigonometry material in vocational high school.

\section{RESEARCH METHOD}

The type of research used is Research and Development (R\&D) research. The research and development are used because researchers want to develop a learning product in the form of Smart Binoculars learning media. Also, when collecting data in the field, namely in the initial research to collect more qualitative data, the next stage of product effectiveness testing is carried out experimentalquantitative methods. Also, the acquisition of data will be analyzed qualitatively-narratively and in the form of quantitative calculations. This type of research and development is considered suitable to be used to assist researchers in developing Smart Binoculars learning media for trigonometry material in class $X$ students and is used to test the effectiveness of the product. By research needs, the place used to develop appropriate learning media is at SMKN 11 Malang.

In this Research and Development Procedure, the researcher refers to the research design and development modification of the development model according to Borg and Gall (Borg \& Gall 2003). This development model consists of ten steps of implementation. The ten steps are not standard things that must be followed, the steps taken can be adjusted to the needs of researchers, with changes as needed in this research and development using 5 stages due to limited time, energy, and cost. Data collection was obtained from the instruments of the assessment of learning tools in the form of validation sheets, test results and student questionnaire responses.

The purpose of data analysis is to describe the validity, practicality, and effectiveness of the media developed. Validation is measured by using a validation sheet through the activity of providing a validation sheet to the validator and has the aim to find out how valid the media and material are developed so that it can be used by students. Practical is measured by using a student response questionnaire through the activities of giving questionnaires to students and has the aim to determine the feasibility of the media. Effectively measured by giving evaluation sheets to students through work on the evaluation questions and have the goal to achieve completeness of the value of trigonometric material.

\section{RESULT AND DISCUSSION}

\section{Media Eligibility}

The research was conducted through a research and Development (R\&D) approach to researchers referring to the Borg and Gall models that have been modified into five phases: research and collection, planning, product draft development, validation, main field 
testing. Therefore, researchers will explain the results of media development by these stages:

Research and collection, from the results of observations conducted by researchers at SMKN 11 Malang. The results of indirect interviews and observations have been conducted, teaching materials used by teachers during the learning process in the classroom using only the package book. Sourced from the results of the analysis, the development of learning media is needed to further streamline the mathematical learning process of trigonometric material in the classroom. One of the learning media developed in the mathematics learning of trigonometric materials is smart binoculars learning media. Product planning is done through the following stages: planning materials and equipment planning and consideration of material and equipment selection are important in the manufacture of media products. Smart Binoculars was developed with the first step in the planning of the necessary materials and equipment. The materials used in the development of the Smart Binoculars media are as follows: plywood with a thickness of $15 \mathrm{~mm}$ to make the media have good durability, bow 360 degrees, and 2 bows 90 degrees. In order to have a low fault rate in the measuring of the researcher to use the finished arc (plastic arc), pipe Paralon serves as a binoculars and also as a pole of this medium itself, Cat Wood and Tiner as a smart media dyes, Pylox Clear is aimed to give more shiny effects and provide staining protection against water. The equipment needed in the development of the Binoculars

Smart Media is as follows: sawing, hammer, drill, nail, sandpaper, markers, brushes, scissors, and insulating papers. It is necessary to develop a mature development process, where the planning aims to make the development process smooth and obtain product results that are suitable for use. Stages of planning the development process starting from planning the initial product development process to the feasibility test in the field. Before the creation of the media, the preparation for the development of the product draft is to prepare the materials needed in the creation of media and content of materials to be used in the media that is trigonometric material (trigonometric comparison) on mathematics in class X. With media learning, teachers can explain trigonometric materials easily. This learning Media can be used by students independently or tutored teachers. Because the media is designed as interesting and easy as possible to understand students. This is different from the research that has been done by Novi Ariyanti (2017), the learning media developed has an advantage in practicality because the tools are very simple and easy to carry where while in terms of use is still lacking. Some things that felt less is the difficulty of use because it requires a minimum of 2 people to use it, the lack of function of the clinometer itself and the accuracy of the value obtained has a relatively large fault rate than that in terms of the display is very simple as quickly make the students bored.

Validation of material experts is a lecturer in mathematics education Faculty of teacher and Education science UMM. The material validity test aims to assess the feasibility of media in terms of material that will be presented in the implementation of learning. This validation is done using a material expert validation poll. The description of the assessment score is as follows. 1 = The assessment aspect does not correspond to the media (invalid/revised), $2=$ The aspect of the assessment is less appropriate to the media (less valid/revised), $3=$ assessment aspect according to the media (valid/not revised), 4 = The assessment aspect is very appropriate with the media (very valid/not revision) 
Table 5: Validation by material experts

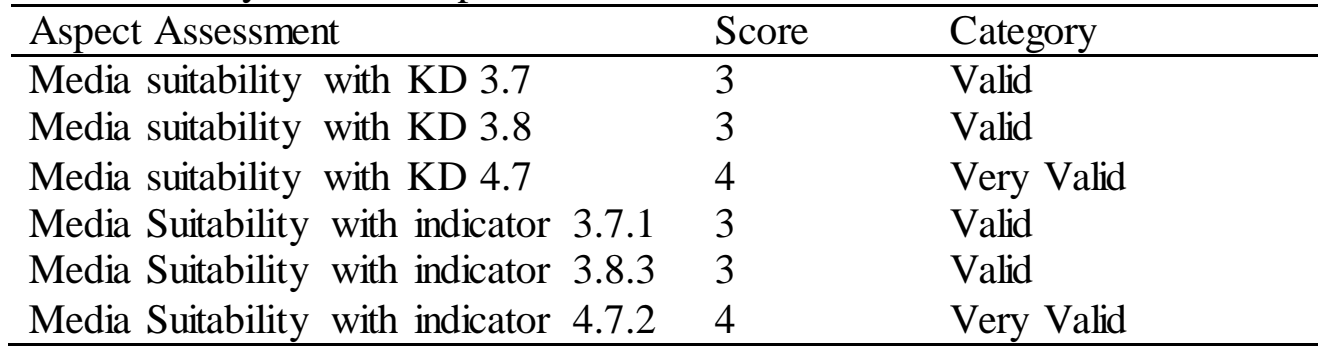

Based on table 5, the relevance assessment gets the result 3.33 and is entered in a valid category. The validation of media experts is a lecturer in mathematics education Faculty of teacher and Educational sciences UMM. Media experts are instrumental in assessing the media feasibility of Smart Binoculars in terms of display, color, writing, association with the material, learning objectives, effective, and practical. The description of the judging score is as follows: 1 = The aspect of the assessment does not correspond to the media (invalid/revised), 2 = The aspect of assessment is less appropriate to the media (less valid/revised), 3 = assessment aspect according to the media (valid/not revised), $4=$ Valuation aspect is very compliant with the media (very valid/not revision

Table 6: Validation by media experts

\begin{tabular}{lll}
\hline Aspect Assessment & Score & Category \\
\hline Interesting media display & 3 & Valid \\
Selection of media colors according & 3 & Valid \\
Number writing on media can be operated without & 3 & Valid \\
constraints & & \\
Media has relevance to the material & 4 & Very Valid \\
Media According to learning objectives & 4 & Very Valid \\
Concrete Media to be used in the learning process & 4 & Very Valid \\
Effective Media in small groups & 3 & Valid \\
Durable Media & 4 & Very Valid \\
Media can be brought anywhere & 3 & Valid \\
Media can be used repeatedly & 4 & Very Valid \\
\hline
\end{tabular}

According to table 6, The relevance assessment aspect gets the result of 3.5 and is entered into a valid category. This is different from the research done by Ahmad Sultoni (2018), in his research validation is only done on the media to his studies without validating the material that corresponds to his learning media.

Small scale trials. The first thing to do is that researchers ask teachers to determine which students will use smart media binoculars, because of the limited media, only 10 students will be selected from various majors in SMKN 11 Malang. Furthermore, teachers convey learning objectives. The teacher introduces Smart binoculars Learning media and explains how to use it. Students are allowed to exit the class to measure using the tools provided and give about 20 minutes. After the completion of observing the students are allowed to write the results of his research in the sheets and also work on and fill the instruments that have been given by the researchers and gathered to the teachers. Teachers together with students conclude the outcome of the research that has been done. Test data retrieval instruments using the enclosed poll (attached). The test of the media product is 
done once, i.e. individual trials. Individual trials were conducted in April 2019 with a test subject of 10 students with 2 learning media. The subject of trials was taken randomly from various majors in SMKN 11 Malang. This is different from the research done by Ahmad Sultoni (2018), the trial was conducted with 12 students from the same class and using only 1 learning medium. It is very inefficient as it will take a long time in the data retrieval process in the field.

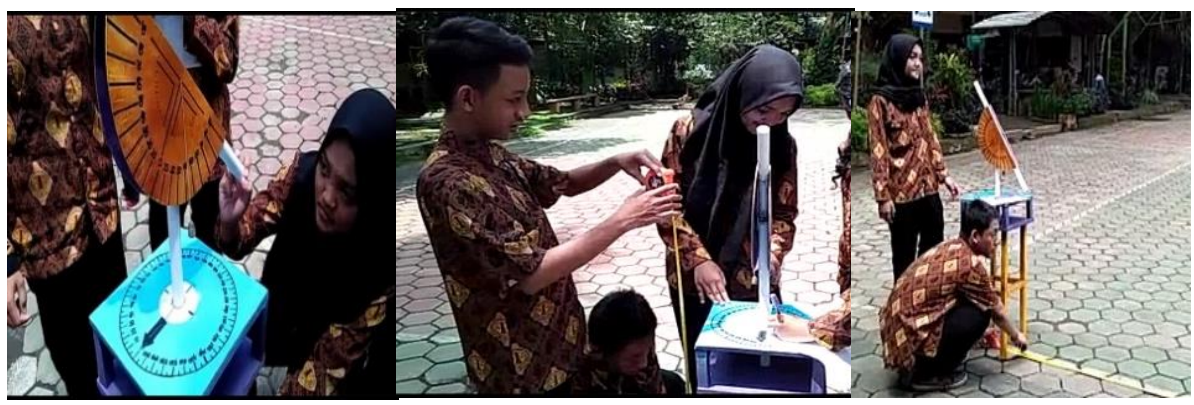

Picture 2. Product Trial

The purpose of this learning media development is to develop Smart Binoculars learning media for trigonometric material in a valid, practical and effective SMK. Kevalidan media and materials have been done in advance at the validation stage. Furthermore, the practicality of this Smart Binoculars is measured using a student response poll. The following will be presented a table to discuss whether the developed learning medium is practical for students to use. The description of the assessment score is as follows: $1=$ very disagree, $2=$ disagree, $3=$ agree, $4=$ very agree. The results of the student response data analysis are presented in table 7 :

Table 7: Student Response Data analys is results

\begin{tabular}{lll}
\hline $\begin{array}{l}\text { Aspect } \\
\text { Assessment }\end{array}$ & Score & Category \\
\hline Interest & 3,43 & Positive \\
Material & 3,47 & Positive \\
\hline Average & 3,44 & Positive \\
\hline
\end{tabular}

Sourced from table 7 data, it can be concluded that the response presented by the students after using the smart Media binoculars learning for trigonometric materials in SMK entered the positive category. It was shown with the results of a response poll data that has been filled by 10 student samples, showing a value of 3.44 with good categories. Furthermore, to determine the effectiveness of media, Smart Binoculars can be measured by looking at the results of the students ' work on the evaluation of a minimum of $80 \%$ above the Minimum submission Criteria 75. Questions were taken based on the questions of National Examination of vocational schools students. From the evaluation of 10 students samples, all got the value above 75 .

\section{Media Development Results}

Research conducted on the subjects of mathematical trigonometric materials in Vocational schools. Media Development Research conducted at SMKN 11 Malang. Respondents in this study were grade $\mathrm{X}$ students of 10 people from various majors. The implementation of this research was conducted in April 2019. The learning activity in this study was conducted in a 1-time meeting with the alloscation time of meetings, 2 hours of 
study. As stated in Implementation of Learning teachers, the use of learning media is given 20 minutes. This research and development resulted in the media learning of smart binoculars that have been validated, tested and remedial. The Final of this learning medium consists of manipulative media that can be used to calculate the height of an object and the width of an object with a specification of 2 bows $90^{\circ}$ to the left and right to determine the angle formed when performing The high measurement of an object and a $360^{\circ}$ bow is in the lower position to calculate the angle magnitudes formed when calculating the width of an object. The results of this research and development are data on the specific needs needed to develop a learning media, about the design and operation of learning media. The feasibility Data of the learning media is derived from the poll calculations during validation by the media experts and the student response questionnaire. As a cosnsideration ingredient, this study refers to earlier studies. Novi Ariyanti (2017), which by applying clinometer learning Media can provide improvement in student learning outcomes. Next up is the study of Ahmad Sultoni (2018) Showing results by applying smart binoculars learning can make an interest in learning and learning outcomes increased. By the two studies above research Noor Fajriah (2017) mentions that the results of his research students have activity in the very active criteria and the ability of mathematical communication of students on high criteria besides students ' responses of the student Clinometer Learning Media is very satisfied

\section{CONCLUSION}

The conclusion of this research and development is as follows. With the media learning of smart binoculars can help the learning process and have fungi to clarify the meaning of the message that you want to convey, to achieve the purpose of education or learning effective, efficient and this media itself has a high level of validity. The research and development procedures used are the modification of Borg and Gall's research and development procedures. Development of Smart Binoculars learning media is done through the steps: Research and collection, planning, development of product drafts, validation, and small scale trials. Based on the results of the evaluation that has been done all students get the value above the KKM then the learning media is categorized very effectively. This use of learning Media also helps students discover each step in their way to make students understand and easy to remember trigonometric materials.

Based on the results of the research and findings during the research, the researchers have some advice that other researchers can apply the mathematical projects in everyday life so that students better understand the mathematical applications in the daily life Days and students are freed in resolving the problem to be resolved.

\section{REFERENCES}

Al. Krismanto. 2008. Pembelajaran Trigonometri SMA. Yogyakarta: PPPPTK Matematika. Anitah, Sri. 2009. Media Pembelajaran. Surakarta: Panitia Sertifikasi Guru Rayon 13 FKIP UNS Surakarta.

Arsyad, Azhar. 2011. Media Pembelajaran. 15th ed. Jakarta: Rajawali Pers.

Azizah, Fathina Rossy, Imam Sujadi, and Henny Ekana Chrisnawati. 2018. "Penerapan Problem Based Learning Pada Materi Luas Permukaan Serta Volume Prisma Dan Limas Ditinjau Dari Kemandirian Belajar Siswa Kelas Viii Smp Negeri 2 Banyudono.” Jurnal Pendidikan Matematika Dan Matematika 2(4):298-306.

Borg \& Gall,2003. Education Research. New York : Allyn and Bacon.

Depdiknas. 2002. Kamus Besar Bahasa Indonesia. 3rd ed. Jakarta: Balai Pustaka. 
Djumanta, Wahyudin and Dwi Susanti. 2008. Belajar Matematika Aktif Dan Menyenangkan. edited by T. S. purna Inves. Jakarta: Pusat Perbukuan.

Dwiatmoko, Aris Ig, Paulina H. Prima Rosa, and Ridowati Gunawan. 2015. "Analisis Statistis Data Ujian Nasional Dan Nilai Sekolah Menengah Atas Di Daerah Istimewa Yogyakarta." Jurnal Ilmiah Widya Teknik 14(2):1-7.

Fajriah, Noor and Selfina Soraya. 2017. "Penerapan Outdoor Learning Dengan Media Klinometer Terhadap Aktivitas Dan Kemampuan Komunikasi Matematis Siswa." Jurnal Review Pembelajaran Matematika 2(1):28-39.

Frick, Heinz. 1979. Ilmu Dan Alat Ukur Tanah. 23rd ed. Yogyakarta: Kanisius.

Kariadinata, Rahayu. 2013. Trigonometri Dasar. 1st ed. Bandung: Pustaka Setia.

Kemendikbud. 2013. "Peraturan Menteri Pendidikan Dan Kebudayaan Republik Indonesia Nomor 70 Tahun 2013 Tentang Kerangka Dasar Dan Struktur Kurikulum Sekolah Menengah Kejuruan/Madrasah Aliyah Kejuruan." Peraturan Menteri Pendidikan Dan Kebudayaan Republikn Indonesia Nomor 70 Tahun 2013 (Standar Penilaian Pendidikan):1-220.

Leong, Deborah J. 2006. The Montessori Method Today. Vol. 24. New York: Frederick A. Stokes Company.

Nugrahanta, Gregoriusari Ari, Catur Rismiati, Andri Anugrahana, and Irine Kurniastuti. 2016. "Pengembangan Alat Peraga Matematika Berbasis Metode Montessori Papan Dakon Operasi Bilangan Bulat Untuk Siswa SD." Jurnal Penelitian (Edisi Khusus PGSD) 20(2):103-16.

Prayitno, Sudi, St Suwarsono, and Tatag Yuli Eko Siswono. 2013. "Komunikasi Matematis Siswa Smp Dalam Menyelesaikan Soal Matematika Berjenjang Ditinjau Dari Perbedaan Gender." Prosiding:Seminar Nasional Matematika Dan Pendidikan Matematika FMIPA UNY (November):565-72.

Rawa, Natalia Rosalina, Akbar Sutawidjaja, Pendidikan Matematika, and Pascasarjana-universitas Negeri Malang. 2016. "Pengembangan Perangkat Pembelajaran Berbasis Model Learning Cycle-7e Pada Materi Trigonometri Untuk Meningkatkan." 1042-55.

Rochmad. 2012. "Desain Model Pengembangan Perangkat Pembelajaran Matematika." Jurnal Kreano 3(1):59-72.

Santyasa, I. Wayan. 2007. Landasan Konseptual Media Pembelajaran. Bali: Workshop Media Pembelajaran.

Sari, Lina Ardila, Suharsono, and Muslim Ansori. 2013. "Hubungan Kekongruenan Dalam Geometri Terhingga.” Prosiding Semirata FMIPA Universitas Lampung 313-18.

Setiawan. 2004. Pembelajaran Trigonometri Berorientasi PAKEM Di SMA. Yogyakarta: PPPG Matematika.

Sugiantara, I. Gusti Putu Ari, Wayan Sadra, and I. Nengah Suparta. 2013. "Pengembangan Perangkat Pembelajaran Matematika Realistik Dengan Peta Konsep Pada Materi Trigonometri Di Kelas XI SMK.” E-Journal Program Pasca Sarjana Universitas Pendidikan Ganesha Program Studi Matematika 2.

Sundayana, Rostina. 2014. MENGENAL MEDIA DAN ALAT PERAGA DALAM PEMBELAJARAN MATEMATIKA. Bandung: ALFABETA.

Widyantini and Sigit. 2010. Pemanfaatan Alat Peraga Dalam Pembelajaran Matematika SMP. Yogyakarta: Departemen Pendidikan Nasional. 